\title{
ACTORS ASSOCIATED WITH PREGNANCY LOSSES IN FRIESIAN COWS RAISED UNDER EGYPTIAN CONDITIONS
}

\author{
Abu El-Hamd, M. A.; A. K. Kadoom; Y.M. El-Diahy and S.H. \\ Hassouna \\ Animal Production Research Institute, Agriculture Research Center, \\ Dokki, Egypt
}

\begin{abstract}
A total of 1,486 records for dairy Friesian cows from 2007-2015 were analyzed to investigation the factors associated with pregnancy losses or abortion raised under Egyptian conditions. The overall incidence of pregnancy losses was $9.89 \%$ in this study. The results showed that the cow age at the conceived insemination in Friesian cows having $\leq 16$ and $\geq 96.1$ months of age was significantly $(P<0.01)$ associated with high incidence of pregnancy losses compared with that having 16.1 to 96 months. Also, extreme body weight at the conceived service was related to pregnancy losses, cows having $\leq 400$ and $\geq 600 \mathrm{~kg}$ of live body weight showed higher percent $(P<0.01)$ of pregnancy losses (13.51 and $20.59 \%$ ) compared to 7.94 and $8.69 \%$ in cows weighted 401 to 499 and 500 to $599 \mathrm{~kg}$ respectively. The cow's parity was significantly $(P<0.01)$ associated with incidence of pregnancy losses, cows had $4^{\text {th }}, 5^{\text {th }}$ and $\geq 6$ parities were higher than that of $1^{\text {st }}, 2^{\text {nd }}$ and $3^{\text {rd }}$ parities. Summer season recorded highest incidence of pregnancy losses compared to the other seasons. In addition, pregnancy losses was higher $(\mathrm{P}<0.01)$ in cows had high milk yield ( $\geq 20 \mathrm{~kg}$ daily milk daily) than cows inlow and moderate milk yield ( $\leq 6$ to $15 \sim 20 \mathrm{~kg}$ daily milk daily) respectively. Nutrition system-1 showed significantly higher $(P<0.01)$ association with the incidence of pregnancy loss compared to nutrition system-2. Either somatic cell count (SCC) or mastitis infection at insemination in Friesian cows were significantly $(\mathrm{P}<0.01)$ high associated with incidence of pregnancy losses in cows having $>400,000 \mathrm{SCC} / \mathrm{ml}$ of milk than that having $\leq 200$ and $\leq 400000 \mathrm{SCC} \backslash \mathrm{ml}$ of milk.
\end{abstract}

Keywords: Friesian cows, pregnancy loss, age, parity, milk yield, mastitis.

\section{INTRODUCTION}

Embryo loss in dairy cows can be classified as early embryonic mortality when cows come back into heat within 25 days after fertilization, and late embryonic mortality (LEM) when losses occur between Days 25 and 45 of gestation (Humblot, 2001). However, abortion as a loss of the fetus between the age of 42 days and approximately 260 days, but calf dead between 260 days and full term is defined a stillbirth (Ganguly, 2015). In dairy cows, abortions showed affected by parity and season. It found higher in party $1(1.4 \%)$ than 
$(1.01 \%)$ party 8 , however, abortions lowest in winter than summer season (Norman et al., 2012).

At best, a cow is only likely to produce a single calf per year. Pregnancy losses are important factors determining the reproductive performance of dairy herds. Conversely, average cost of a pregnancy loss was estimated at $\$ 555$ but varied depending on days in milk at conception and stage of gestation when the pregnancy is lost (De Vries, 2006).

Silke et al., (2002) recorded that milk production effect on embryo loss and the rate between days 24 and 80 , the embryo losses were $7 \%$ in lactating cows and 6\% approximately in heifers with $48 \%$ of these losses occurred between days 28 and 42 of gestation. However, in intensively managed dairy cows yielding between 11,000 and $12,000 \mathrm{~kg}$ of milk per lactation $20 \%$ of embryos were lost between days 28 and 98 of gestation (Vasconcelos et al., 1997). Circulating progesterone concentrations decreases in high milk production of Holstein cows. During gestation, progesterone influences embryo development, stimulates interferon-tau production, and inhibits the luteolytic cascade (Shahneh et al., 2008). The occurrence of clinical mastitis after pregnancy examination has been associated with increased pregnancy loss. In one study, cows with clinical mastitis between artificial insemination (Al) and day 45 after Al were 2.8 times more likely to lose their pregnancy as compared to healthy cows (Chebel et al., 2004). In U.S. dairy herds, cows with reducedBCS either at calving or at the time of the first postpartum Al are at a greater risk of losing their pregnancies from day 30 to 58 of gestation (Santos et al., 2009). Therefore, the objectives of this study were to determine the effects of age, live body weight, parity, season of year, milk yield, nutrition and mastitis on the incidence of pregnancy loss of Friesian cows under the Egyptian condition.

\section{MATERIALS AND METHODS}

The data of 1486 records of Friesian cows raised at Sakha station, Animal Production Research Institute (APRI), Egypt, from 2007 to 2015 that were culled from the herd were used in this study. Data of each cow record include birth date, live body weight at conceived serviceparity, season of year, and milk yield. From these data, the following traits were statistically calculated:

1- Age at the conceived service was classified into different groups ( $\leq 16,16.1$ to $24,24.1$ to $50,50.1$ to $72,72.1$ to 96 and $\geq 96.1$ months).

2- Live body weight was divided into four different groups $(\leq 400$, 401 to 499,500 to 599 and $\geq 600 \mathrm{~kg}$ ).

3- Parities of each cow. 
4- Daily milk yield $(\mathrm{kg})$ and its frequency.

5- Reproductive season (spring, summer, autumn and winter).

6- Nutrition systems (two systems).

7- Somatic cell counts (SCC/) dose to the concerned date infection classified according to the rate of infection $(\leq 200.000$, 201.000 to $300.000,301.000$ to $400.000,401.000$ to 500.000 , 501.000 to 600.000 and $\geq 600.000 \mathrm{SCC} / \mathrm{ml} \mathrm{milk}$ ).

Free mastitis $=$ SCC $\leq 400.000$ cells $/ \mathrm{ml}$ milk, subclinical mastitis $=$ SCC 400.000: 600.000 cells $/ \mathrm{ml}$ milk andclinical mastitis $\geq 600.000$ /cells/ml milk.

Management and feeding:

During the period from 2007 to 2015, all animals were farm fed in- group according to their body weight, milk production and reproductive status. Cows were fed on concentrate feed mixture (CFM), maize silage (MS) and rice straw (system 1) from June to the end of October. While, from November up to the end of April, animals were fed CFM, fresh berseem and rice straw (system 2). The concentrate feed mixture was offered twice daily at about 8.0 a.m. and 2.0 p.m. while rice straw and the drinking water were available for all cows along the daily time. All lactating Friesian cows were machine milked twice daily at 6 a.m. and 5 p.m. out the milking time, all cows were kept untied in semi-open and shaded yard. The examination of reproductive tract of all animals by rectal palpation revealed that the genitalia of all animals were free from any pathological diseases and disorders.

\section{Statistical Analysis:}

The obtained data were statistically analyzed using SAS (2004) to determine the factors associated with the incidence of pregnancy loss in Friesian cows raised under the Egyptian condition. The data were analyzed according to Snedecor and Cocharn (1989) and the statistical model was:

$Y_{i j}=U+A_{i}+e_{i j}$.

Where:

$\mathrm{Y}_{\mathrm{ij}}=$ Observed values.

$\mathrm{U}=$ Overall mean .

$A_{i}=$ Animals (normal pregnancy and loss).

$\mathrm{e}_{\mathrm{ij}}=$ Random error.

Chi-square was used to test the differences between the normal pregnancy and pregnancy loss. Duncan Multiple Range test (Duncan, 1955) was used to get the mean separations between normal pregnancy and pregnancy loss. 


\section{RESULTS AND DISCUSSION}

Based on the data recorded and statically analyzed, several factors appear related to pregnancy loss in Friesian cows raised under the Egyptian conditions.

\section{Age at conceived insemination:}

Age at insemination of conception shows a highly significant $(P<0.05)$ effect of the pregnancy loss in Friesian cows $\leq 16$ and $\geq 96.1$ months of extremely low age ( $\leq 16$ moth) and extremely old ( $\geq 96$ moth) than the other cows at the different ages of pregnant (Table 1).

Table 1: Effect of different ages at insemination and its frequency on pregnancy loss in Friesian cows

\begin{tabular}{|c|c|c|c|c|c|}
\hline \multirow{2}{*}{$\begin{array}{c}\text { Age at pregnant } \\
\text { (month) }\end{array}$} & \multirow{2}{*}{$\begin{array}{c}\text { Total animal } \\
\text { pregnant }\end{array}$} & \multicolumn{2}{|c|}{ Pregnancy normal } & \multicolumn{2}{|c|}{ Pregnancy loss } \\
\cline { 3 - 6 } & $\mathbf{3}$ & No. & $\%$ & No. & $\%$ \\
\hline $\mathbf{1 6}$ & 34 & 25 & $73.53^{\mathrm{c}}$ & 9 & $26.47^{\mathrm{a}}$ \\
\hline $\mathbf{1 6 . 1} \sim \mathbf{2 4}$ & 157 & 141 & $89.81^{\mathrm{a}}$ & 16 & $10.19^{\mathrm{c}}$ \\
\hline $\mathbf{2 4 . 1} \sim \mathbf{5 0}$ & 477 & 434 & $90.99^{\mathrm{a}}$ & 43 & $9.01^{\mathrm{c}}$ \\
\hline $\mathbf{5 0 . 1} \sim \mathbf{7 2}$ & 391 & 363 & $92.84^{\mathrm{a}}$ & 28 & $7.16^{\mathrm{c}}$ \\
\hline $\mathbf{7 2 . 1} \sim \mathbf{9 6}$ & 237 & 217 & $91.56^{\mathrm{a}}$ & 20 & $8.44^{\mathrm{c}}$ \\
\hline $\mathbf{2 9 6 . 1}$ & 190 & 159 & $83.68^{\mathrm{b}}$ & 31 & $16.32^{\mathrm{b}}$ \\
\hline Overall mean & $\mathbf{1 4 8 6}$ & $\mathbf{1 3 3 9}$ & $\mathbf{9 0 . 1 1}$ & $\mathbf{1 4 7}$ & $\mathbf{9 . 8 9}$ \\
\hline
\end{tabular}

a ,b, c Means denoted within the same column, with different superscripts are significantly different at $\mathrm{P}<0.05$.

The age of cows at the final fertilized insemination (service of conception) in young age and old age cows were associated with increase embryo or fetal losses by 26.47 and $16.32 \%$, respectively than the moderate age (7.16 to $9.03 \%$,Table 1$)$. The incidence of pregnancy loss in heifers inseminated at 16 to 24 months of age showed lower (10.19\%) than that the older cows having more than 96 months of age (16.32\%). The results are in agreement with that reported by Thurmond et al. (1990a) who reported that the abortion rate increased after cows reached 5 year of age. Heifers are generally considered to have higher pregnancy rates, and this increase seems to be associated with less embryonic mortality than in cows (Geary, 2005). Among dairy cattle, an increase of both early and late embryonic losseswas reported in cows with the increase of age (Humbolt, 2001; Starbuck et al., 2004).

\section{Live body weight:}

The data presented in Table 2 demonstrate the relationship between cows live body weight and the incidence pregnancy loss. Pregnancy loss showed significantly higher $(P<0.01)$ in cows with $\leq 400$ and $\geq 600 \mathrm{~kg}$ live body weight (13.51 and $20.59 \%$, respectively) 
compared to the other cows with401 499 and $500 \sim 599 \mathrm{~kg}$ by about 7.94 and $8.69 \%$, respectively (Table 2 ).

Table 2: Effect of live body weight $(\mathrm{kg})$ and its frequency on the incidence of pregnancy loss in Friesian cows raised in Egypt

\begin{tabular}{|c|c|c|c|c|c|}
\hline \multirow{2}{*}{ Body weight (kg) } & $\begin{array}{c}\text { Total animal } \\
\text { pregnant }\end{array}$ & \multicolumn{2}{|c|}{ Pregnancy normal } & \multicolumn{2}{|c|}{ Pregnancy loss } \\
\cline { 3 - 6 } & 37 & No. & $\%$ & No. & $\%$ \\
\hline$\leq \mathbf{4 0 0}$ & 32 & $86.49^{\circ}$ & 5 & $13.51^{\mathrm{b}}$ \\
\hline $\mathbf{4 0 1} \sim \mathbf{4 9 9}$ & 554 & 510 & $92.06^{\mathrm{a}}$ & 44 & $7.94^{\mathrm{c}}$ \\
\hline $\mathbf{5 0 0} \sim \mathbf{5 9 9}$ & 725 & 662 & $91.31^{\mathrm{a}}$ & 63 & $8.69^{\mathrm{c}}$ \\
\hline $\mathbf{2} \mathbf{6 0 0}$ & 170 & 135 & $79.41^{\mathrm{c}}$ & 35 & $20.59^{\mathrm{a}}$ \\
\hline Overall mean & 1486 & 1339 & 90.11 & 147 & 9.89 \\
\hline
\end{tabular}

${ }^{c}$ Means denoted within the same column, with different superscripts are significantly different at $\mathrm{P}<0.05$.

\section{Parity:}

Data in Table 3 show that cows parity was significantly $(P<0.01)$ affect the incidence of pregnancy loss or abortionin Friesian cows raised in Egypt. The incidence of pregnancy losses showed significantly higher $(\mathrm{P}<0.01)$ in cadence cows with 5 and $\geq 6$ parities $(14.42 \%$ and $15.59 \%)$ compared with that of $1^{\text {st }}, 2^{\text {nd }}$ or $3^{\text {rd }}$ parities $(7.83$, 8.83 and $8.41 \%$, respectively). Some of cows that frequently aborted abortions during earlier lactations must culled (Peter, 2000). Santos et al. (2004a) reported that pregnancy loss was $10.7 \%$ for lactating cows and $4.2 \%$ for dairy heifers whereas, Thurmond et al. (1990b) reported that abortion rate was higher among cows that had experienced a previous abortion compared with those that had not. All causes of higher abortion frequencies for earlier parities are unknown, although parities differences in traits such as dystocia and stillbirth have been reported (Cole et al. 2007; Zaborski et al. 2009; Norman et al. 2010).It would be expected to have an effect on subsequent reproductive health. A contrasting result were reported by Thurmond et al. (1990b), who found that abortion rate increased after cows reached after 5 pregnancies, or after 4 calving.On theother hand, Norman et al. (2012) found that frequency of abortions was $1.40 \%$ for parity 1 and $1.01 \%$ for parity $\geq 8$ in dairy herd improvement-recorded.

Table 3: Incidence of pregnancy loss in Friesian cows raised under the Egyptian conditions in relation to parity

\begin{tabular}{|c|c|c|c|c|c|}
\hline \multirow{2}{*}{ Parity } & \multirow{2}{*}{$\begin{array}{c}\text { Total animal } \\
\text { pregnant }\end{array}$} & \multicolumn{2}{|c|}{ Pregnancy normal } & \multicolumn{2}{|c|}{ Pregnancy loss } \\
\cline { 3 - 7 } & & No. & $\%$ & No. & $\%$ \\
\hline $\mathbf{1}$ & 447 & 412 & $92.17^{\mathrm{a}}$ & 35 & $7.83^{\mathrm{c}}$ \\
\hline $\mathbf{2}$ & 351 & 320 & $91.17^{\mathrm{ab}}$ & 31 & $8.83^{\mathrm{bc}}$ \\
\hline $\mathbf{3}$ & 226 & 207 & $91.59^{\mathrm{a}}$ & 19 & $8.41^{\mathrm{c}}$ \\
\hline $\mathbf{4}$ & 172 & 154 & $89.53^{\mathrm{b}}$ & 18 & $10.47^{\mathrm{b}}$ \\
\hline $\mathbf{5}$ & 104 & 89 & $85.58^{\mathrm{c}}$ & 15 & $14.42^{\mathrm{a}}$ \\
\hline $\mathbf{2 6}$ & 186 & 157 & $84.41^{\mathrm{c}}$ & 29 & $15.59^{\mathrm{a}}$ \\
\hline Overall mean & $\mathbf{1 4 8 6}$ & $\mathbf{1 3 3 9}$ & $\mathbf{9 0 . 1 1}$ & $\mathbf{1 4 7}$ & $\mathbf{9 . 8 9}$ \\
\hline
\end{tabular}


$a, b, c$ Means denoted within the same column, with different superscripts are significantly different at $\mathrm{P}<0.05$.

\section{Daily milk yield:}

Data in Table (4) indicated that milk yield was significantly $(P<0.05)$ associated with the incidence of pregnancy loss in high milk yield cows (equal or more than $20 \mathrm{~kg}$ daily milk yield) compared with moderate and low milk yielder ( $\leq 6$ to $15 \mathrm{~kg}$ daily milk yield).

Table 4: Incidence pregnancy loss in Friesian cows raised in Egypt in relation to milk yield $(\mathrm{k} \mathrm{g})$

\begin{tabular}{|c|c|c|c|c|c|}
\hline \multirow{2}{*}{ Milk yield $\mathbf{( k g )}$} & \multirow{2}{*}{$\begin{array}{c}\text { Total animal } \\
\text { pregnant }\end{array}$} & \multicolumn{2}{|c|}{ Pregnancy normal } & \multicolumn{2}{c|}{ Pregnancy loss } \\
\cline { 3 - 6 } & & No. & $\%$ & No. & $\%$ \\
\hline $\mathbf{5 6}$ & 72 & 66 & $91.67^{\mathrm{a}}$ & 6 & $8.33^{\mathrm{C}}$ \\
\hline $\mathbf{6 . 1} \sim \mathbf{1 0}$ & 305 & 277 & $90.82^{\mathrm{a}}$ & 28 & $9.18^{\mathrm{c}}$ \\
\hline $\mathbf{1 0 . 1} \sim \mathbf{1 5}$ & 761 & 691 & $90.80^{\mathrm{a}}$ & 70 & $9.20^{\mathrm{C}}$ \\
\hline $\mathbf{1 5 . 1} \sim \mathbf{2 0}$ & 249 & 221 & $88.75^{\mathrm{b}}$ & 28 & $11.25^{\mathrm{b}}$ \\
\hline $\mathbf{2 0}$ & $\mathbf{2 0}$ & 84 & $84.85^{\mathrm{c}}$ & 15 & $15.15^{\mathrm{a}}$ \\
\hline Overall mean & 1486 & 1339 & 90.11 & 147 & 9.89 \\
\hline
\end{tabular}

${ }^{\mathrm{C}}$ Means denoted within the same column, with different superscripts are significantly different at $\mathrm{P}<0.05$.

The present results are in agreement with that of Norman et al. (2012), who reported that cows in the high yield had higher abortion rates $(1.39$ to $1.53 \%)$ than cows in a low daily milk yield (0.76 to $0.98 \%$ ). The historic trend for increased milk yield per cow (Animal Improvement Programs Laboratory, 2011b) may have contributed to increased abortions over time. One of the consequences of high milk production is an increased metabolic rate linked to a greater dry matter intake. This process reduces plasma concentrations of steroid hormones such as progesterone (Sangsritavong et al., 2002). In fact, milk production can affect negatively plasma progesterone concentrations at the onset of the fetal period (Bech-Sàbat et al., 2008; Rhinehart et al., 2009). Therefore, it seems reasonable to suppose that one of the causes of early fetal loss in high producing dairy cows could be due to the suboptimal concentrations of progesterone. Thus, strategies that induce the formation of an additional corpus luteum may help to increase progesterone levels in high producers cows, although treatment with $\mathrm{GnRH}$ at Al (López-Gatius et al., 2006) and with $\mathrm{GnRH}$ or hCG at pregnancy diagnosis (Bartolomé et al., 2006; Stevenson et al., 2008) clearly increase the number of additional corpora lutea, those treatment did not reduce fetal loss in any. 


\section{Seasons:}

Data presented in Table (5) showed that in summer season pregnancy loss in Friesian cows was significantly $(P<0.01)$ higher $(12.25 \%)$ than other seasons $(6.89,8.85$ and $9.27 \%$ in winter, spring and autumn seasons, respectively). In addition, pregnancy loss showed significantly correlated with the month, in which a successful insemination was performed. It was found that pregnancy loss up to 90 day of its development occurred most frequently after inseminations performed in April $(P=0.027)$, and most seldom after cows insemination in August (Gehrke and Zbylut, 2011).

Table 5: Incidence of pregnancy loss in Friesian cowsraised under the Egyptian conditions in relation to season

\begin{tabular}{|c|c|c|c|c|c|}
\hline \multirow{2}{*}{ Season } & \multirow{2}{*}{$\begin{array}{c}\text { Total animal } \\
\text { pregnant }\end{array}$} & \multicolumn{2}{|c|}{ Pregnancy normal } & \multicolumn{2}{c|}{ Pregnancy loss } \\
\cline { 3 - 6 } & 399 & No. & $\%$ & No. & $\%$ \\
\hline Spring & 362 & $90.73^{\mathrm{a}}$ & 37 & $9.27^{\mathrm{b}}$ \\
\hline Summer & 341 & 289 & $84.75^{\mathrm{b}}$ & 52 & $15.25^{\mathrm{a}}$ \\
\hline Autumn & 339 & 309 & $91.15^{\mathrm{a}}$ & 30 & $8.85^{\mathrm{b}}$ \\
\hline Winter & 407 & 379 & $93.11^{\mathrm{a}}$ & 28 & $6.89^{\mathrm{b}}$ \\
\hline Overall mean & $\mathbf{1 4 8 6}$ & $\mathbf{1 3 3 9}$ & $\mathbf{9 0 . 1 1}$ & $\mathbf{1 4 7}$ & $\mathbf{9 . 8 9}$ \\
\hline
\end{tabular}

${ }^{, C}$ Means denoted within the same column, with different superscripts are significantly different at $\mathrm{P}<0.05$.

The present results are in agreement with that of Al-Samarai et al. (2012) who found that the highest pregnancy loss ratio in summer and spring, whereas the lowest was in winter and autumn. The significant differences between estimates may belonged to high temperature degrees which could caused heat stress and abortion in animals. Hovingh (2009) reported that heat stress can affect reproductive performance in dairy herd, causing a conception problems rather than abortions. While, there is some evidence to suggest that a very sudden increase in environmental temperature may result in abortion. There was little evidence to support heat stress as a common cause of pregnancy loss or abortion. Jordan (2003) reported that negative effects of heat stress have been identified from 42 day before to 40 day after insemination which was representing synchronization between heat stress and each of early and late pregnancy loss.

In dairy cattle, short term heat stress at the time of breeding or within the $1^{\text {st }}$ week after breeding appears to be the most deleterious time for due to elevated temperatures, asa results of in delayed embryonic development that eventually becomes "out of sync" with its maternal environment. The previous results may explained by the finding of Biggers et al. (1987) and Geisert et al. (1988) who reported that the cowsexposed to heat stress from day 8 to 16 after breeding 
had decreased progesterone concentration and increased uterine prostaglandin secretion.

\section{Nutrition:}

Data presented in Table 5 showed that nutrition in Friesian cows were significantly $(P<0.01)$ associated withthe incidence pregnancy loss in system 1 than in system 2 .Nutrition in system 1 was containing fresh berseem higher in energy and protein levels, minerals and vitamins compared in nutrition 2 containing maize silage lower in protein levels. The results are in agreement with that of Wiltbank et al. (1962), who found that the effect of nutrition on embryonic mortality and failure of fertilization are correlated with the embryonic mortality. However, it was known that energy and protein levels play a role in maintaining pregnancy, therefore, it is essential for cows to be in adequate condition in order to minimize embryonic loss. When producers can manage body condition by scoring the cows body condition several months before breeding and adjusting diets according to specific needs. Cows will have less embryonic mortality if they are gaining suitable condition, whereas, those losing condition will tend to have higher embryonic loss (Wiltbank et al., 1962).

It has been documented that an excess of protein will increase embryo mortality (Blanchard et al., 1990; Elrod et al., 1993). Excess levels of dietary protein could possibly alter hormone secretion, such as progesterone, in the uterus or could increase blood urea concentrations. These changes could be toxic to the developing embryo. Dairy cattle fed high protein diets are usually exposed to this problem (Kaim et al., 1983).

Table 6: Incidence of pregnancy loss in Friesian cows raised in Egypt in relation to nutrition system

\begin{tabular}{|c|c|c|c|c|c|}
\hline \multirow{2}{*}{ Items } & \multirow{2}{*}{$\begin{array}{c}\text { Total animal } \\
\text { pregnant }\end{array}$} & \multicolumn{2}{|c|}{ Pregnancy normal } & \multicolumn{2}{|c|}{ Pregnancy loss } \\
\hline & & No. & $\%$ & No. & $\%$ \\
\hline System 1 & 740 & 651 & $87.97^{\circ}$ & 89 & $12.03^{\mathrm{a}}$ \\
\hline System 2 & 746 & 688 & $92.33^{\mathrm{a}}$ & 58 & $7.77^{b}$ \\
\hline Overall mean & 1486 & 1339 & 90.11 & 147 & 9.89 \\
\hline
\end{tabular}

\section{Somatic cell counts (SCC) or mastitis:}

The data presented in Table 7 showed that the SCC or mastitis infectionat insemination time in pregnancy losscows were significantly $(\mathrm{P}<0.01)$ more than $400000 \mathrm{SCC} / \mathrm{ml}$ (subclinical mastitis) and highly significantly $(P<0.001)$ in cowsassociated with 600.000 cell per $\mathrm{ml}$ (clinical mastitis) . 
Mastitis infection can be caused by either gram-negative or gram-positive organisms. The former releases endotoxins from its lipopolysaccharides-containing cell wall that can induce endogenous release of PGF2 $\alpha$. In addition, similar to gram-negative, grampositive bacteria can cause inflammatory responses, pyrexia, and septic shock. It is known that mastitis, either clinical or subclinical, is associated with reduced conception rates in dairy cattle (Schrick et al., 2001). Several epidemiological studies have indicated a strong relationship between mastitis and risk of pregnancy loss in lactating dairy cows. Risco et al. (1999) evaluated the risk of fetal loss in 2087 cows diagnosed pregnant, They concluded that cows diagnosed with clinical mastitis during the first $45 \mathrm{~d}$ of gestation were at 2, 7 (95\% confidence interval $=1,3$ to 5,6 ) times greater risk of abortion within the next 90 day of gestation than herdmates without mastitis.

Table 7: Pregnancy lossesin Friesian cows in relation to somatic cell counts (SCC)

\begin{tabular}{|c|c|c|c|c|c|}
\hline \multirow{2}{*}{$\mathbf{S C C} \times \mathbf{1 0 6}$} & \multirow{2}{*}{$\begin{array}{c}\text { Total animal } \\
\text { pregnant }\end{array}$} & \multicolumn{2}{|c|}{ Pregnancy normal } & \multicolumn{2}{|c|}{ Pregnancy loss } \\
\cline { 3 - 6 } & $\mathbf{N 3 6}$ & 321 & $95.54^{\mathrm{a}}$ & No. & $\%$ \\
\hline $\mathbf{2 0 0}$ & 315 & $4.46^{\mathrm{e}}$ \\
\hline $\mathbf{2 0 1} \sim \mathbf{3 0 0}$ & 315 & 297 & $94.29^{\mathrm{ab}}$ & 18 & $5.71^{\mathrm{de}}$ \\
\hline $\mathbf{3 0 1} \sim \mathbf{4 0 0}$ & 236 & 217 & $91.95^{\mathrm{b}}$ & 19 & $8.05^{\mathrm{d}}$ \\
\hline $\mathbf{4 0 1} \sim \mathbf{5 0 0}$ & 216 & 190 & $87.96^{\mathrm{c}}$ & 26 & $12.04^{\mathrm{c}}$ \\
\hline $\mathbf{5 0 1} \sim \mathbf{6 0 0}$ & 224 & 188 & $83.93^{\mathrm{d}}$ & 36 & $16.07^{\mathrm{b}}$ \\
\hline $\mathbf{2 6 0 0}$ & 159 & 126 & $79.25^{\mathrm{e}}$ & 33 & $20.75^{\mathrm{a}}$ \\
\hline Overall mean & $\mathbf{1 4 8 6}$ & $\mathbf{1 3 3 9}$ & $\mathbf{9 0 . 1 1}$ & $\mathbf{1 4 7}$ & $\mathbf{9 . 8 9}$ \\
\hline
\end{tabular}

${ }^{2 C}$ Means denoted within the same column, with different superscripts are significantly different at $\mathrm{P}<0.05$.

The present results are in agreement with that of Santos et al. (2004b) who found that animals withdeveloping mastitis prior to artificial insemination (AI) fromAl to pregnancydiagnosis, and after pregnancydiagnosis had greater incidence ofpregnancy loss and abortion than that not developing mastitisthroughout lactation period. Similarly, Chebel et al. (2004) observed that the incidence of clinical mastitis between pregnancy diagnosis and reconfirmation was associated with increase of late embryonic loss $(P=0,02)$. Cows experiencing clinical mastitis were 2,80 (95\% confidence intervaltimes more likely to lose their pregnancy than those not experiencing mastitis. In pasture-based systems, clinical mastitis was also associated with risk for pregnancy loss (McDougall et al., 2005). Therefore, it is clear that clinical mastitis found associated with the increasing risk for pregnancy loss, although it is less clear whether this is a direct causal relationship or that the underlying mechanisms leading to mastitis that also influence the maintenance of pregnancy in cattle. Day of Al to pregnancy reconfirmation was associated with the 
increase of pregnancy loss. McDougall et al. (2005) found that the highest rate of pregnancy loss occurred in early gestation. Clinical mastitis, anoestrus and calving late in the calving season were risk factors for pregnancy loss.

Age of fetal loss and its frequency:

Data in Table (8) show that intrauterine age of fetal lost and its frequency were significantly $(\mathrm{P}<0.05)$ higher in late trimester $(39.46 \%)$ than in early and mid cows (14.97 and $10.88 \%$, respectively) of total cows pregnancy loss (147 cows pregnancies).

Table 8: Intrauterine life age of Friesian cows pregnancy loss along the pregnancy period

\begin{tabular}{|c|c|c|c|}
\hline \multirow{2}{*}{ Age of fetal loss (days) } & \multicolumn{3}{|c|}{ Pregnancy loss } \\
\cline { 2 - 4 } & $\mathbf{N}$ & $\begin{array}{c}\text { \% of } \\
\text { pregnancy loss }\end{array}$ & $\begin{array}{c}\text { \% of } \\
\text { total animals }\end{array}$ \\
\hline $\mathbf{4 2 \sim 1 5 6 ^ { ( 1 ) }}$ & 16 & $10.88^{\mathrm{b}}$ & $1.08^{\mathrm{b}}$ \\
\hline $\mathbf{1 5 7} \sim \mathbf{2 0 0}^{(2)}$ & 22 & $14.97^{\mathrm{b}}$ & $1.48^{\mathrm{b}}$ \\
\hline $\mathbf{2 0 1} \sim \mathbf{2 5 9}^{(3)}$ & 58 & $39.46^{\mathrm{a}}$ & $3.90^{\mathrm{a}}$ \\
\hline $\mathbf{2 6 0 ^ { ( 4 ) }}$ & 51 & $34.69^{\mathrm{a}}$ & $3.43^{\mathrm{a}}$ \\
\hline Total & $\mathbf{1 4 7}$ & $\mathbf{1 0 0}$ & $\mathbf{9 . 8 9}$ \\
\hline
\end{tabular}

:Means denoted within the same column, with different superscripts are significantly different at $P<0.05$. (1) early pregnancy loss, (2) mid pregnancy loss, (3) late pregnancy loss, (4) still birth and * number of total animals pregnant is 1486 cows.

The results are in agreement with that of Hovingh (2009) who, reported that fetal loss occurs in high gestation than early, also, Kirk (2003) and Forar (1996) reported that $10.8 \%$ fetal loss between 31 and 260 days of gestation in Holstein cows.

In this study the overall mean incidence of pregnancy loss was $9.89 \%$ (Jousan et al., 2005) found that the incidence of pregnancy loss in dairy cows in ranges between $0.4 \%$ and $10.6 \%$ and usually is higher in cows than in heifers and is more frequently during the first trimester of pregnancy.

\section{CONCLUSION}

The current study concluded that the incidence of pregnancy losses in Friesian cows increased in cows aged $\leq 16$ and $\leq 96.1$ months, weighted $\leq 400$ and $\geq 600 \mathrm{~kg}$ live body weight, parities more than 4, summer season, high milk yield (equal or more than $20 \mathrm{~kg}$ daily milk daily) and having aclinical mastitis or SCC more than 400000 $\mathrm{SCC} / \mathrm{ml}$ and more than $600000 \mathrm{cell} / \mathrm{mlin}$ Egypt. As a results, pregnancy losses in Friesian cows in this study were affected by season, parity, milk yield and mastitis. 


\section{REFERENCES}

Al-Samarai, F.R.; Y.K. Abdulrahman; I. Wafaa; Ibrahim and A.M. AlNedawi (2012). Effect of some environmental factors on abortion and offspring sex ratio in Holstein cows in Iraq. I.J.S.N., Vol. 3(2): 361-365.

Bartolome, J.A.; S. Kamimura; F. Silvestre; A.C.M. Arteche; T. Trigg and W.W. Thatcher (2006). The use of a deslorelin implant (GnRH agonist) during the late embryonic period to reduce pregnancy loss. Theriogenology, 65:1443-1453.

Bech-Sàbat, G.; F. López-Gatius; J.L. Yániz; I. García-Ispierto; P. Santolaria; B. Serrano; J.Sulon; N.M. de Sousa and J.F. Beckers (2008). Factors affecting plasma progesterone in the early fetal period in high producing dairy cows. Theriogenology, 69:426-432.

Biggers, B.G.; R.D. Geisert; R.P. Wetteman and D.S. Buchanan (1987). Effect of heat stress on earlyembryonic development in the beef cow. J. Anim. Sci., 64:1512-1528.

Blanchard, T.; J. Ferguson; L. Love; T. Takeda; B. Henderson; J. Hasler and W. Chalupa (1990). Effect of Dietary Crude-Protein Type on Fertilization and Embryo Quality in Dairy Cattle. Am. J. Vet. Res., 51:905.

Chebel, R.C.; J.E.P. Santos; J.P. Reynolds; R.L.A. Cerri; S.O. Juchem and $M$. Overton (2004). Factors affecting conception rate after artificial insemination and pregnancy loss in lactating dairy cows. Anim. Reprod. Sci., 84: 239-255.

Cole, J.B.; G.R. Wiggans and P.M. VanRaden (2007). Genetic evaluation of stillbirth in United States Holsteins using sire-maternal grandsire threshold model. J. Dairy Sci., 90:2480-2488.

De Vries, A. (2006). Economic value of pregnancy in dairy cattle. J. Dairy Sci., 89:3876-3885.

Duncan, D. B. 1955. Multiple ranges and multiple F-test. Biometrics, 11:1-42.

Elrod, C.C., and W.R. Butler (1993). Reduction of Fertility And Alteration of Uterine Ph In Heifers Fed Excess Ruminally Degradable Protein. J. Anim. Sci., 71:694.

Forar, A.L.; J.W. Gay; D.D. Hancock and C.C. Gay (1996). Fetal loss frequency in ten Holstein dairy herds. Theriogenology, 45:15051513.

Ganguly, S.(2015). An overview on various reported causes of abortion and still birth in dairy cattle. World J. Biol. Med. Sci., Vol. 2 (1), 3334.

Geary, T. (2005). Management Strategies to Reduce Embryonic Loss. Proceedings, The Range Beef Cow Symposium XIX December 6, 7 and 8, 2005, Rapid City, South Dakota.

Gehrke, M. and J. Zbylut (2011). Factors connected with pregnancy loss in dairy cows. Bull Vet InstPulawy, 55, 457-464.

Geisert, R.D.; M.T. Zavy and B.G. Biggers (1988). Effect of heat stress on conceptus and uterine secretion in the bovine. Theriogenology, 29:1075-1082. 
Hovingh, E. (2009). Abortions in dairy cattle. 1. Common causes of abortions. http://.vir. coo. ext.

Humbolt, P. (2001). Use of pregnancy specific proteins and progesterone assays to monitor pregnancy and determine the timing, frequencies and sources of embryonic mortality in ruminants. Theriogenology, 56:1417-1433.

Jordan, E.R. (2003). Effects of heat stress on reproduction. J. Dairy Sci., 86:104-114.

Jousan, F.D.; M. Drost and P.J. Hansen (2005). Factors associated with early and mid-to-late fetal loss in lactating and nonlactating Holstein cattle in a hot climate. J. Anim. Sci., 83, 1017-1022.

Kaim, M.; Y. Folman; H. Neumark and W. Kaufman (1983). The Effect of protein intake and lactation number on postpartum bodyweight loss and reproductive performance of dairy cows. Anim. Prod., 37:229.

Kirk, J.H (2003). Infectious abortions in dairy cows. Vet. Med. Ext. Fact. Sheet, Univ. of California, Davis. Accessed Sep. 21, 2011.

López-Gatius F.; P.Santolaria; A. Martino; F. Delétang and F. De Rensis (2006). The effects of GnRH treatment at the time of Al and 12 days later on reproductive performance of high producing dairy cows during the warm season in northeastern Spain. Theriogenology, 65:820-830.

McDougall, S.; F.M .Rhodes and G.A. Verkerk (2005). Pregnancy loss in dairy cattle in the Waikato region of New Zealand. N. Zeal Vet. J., 53: 279-287.

Norman, H.D.; J.L. Hutchison and R.H. Miller (2010). Use of sexed semen and its effect on conception rate, calf sex, dystocia, and stillbirth of Holsteins in the United States. J. Dairy Sci., 93:3880-3890.

Norman, H.D.; R.H. Miller; J.R. Wright; J.L. Hutchison and K.M. Olson (2012). Factors associated with frequency of abortions recorded through Dairy Herd Improvement test plans. J. Dairy Sci., 95 :4074-4084.

Peter, A.T. (2000). Abortions in dairy cows: New insights and economicimpact. Adv. Dairy Technol. 12:233-244.

Rhinehart, J.D.; M.J. Starbuck-Clemmer; J.A. Flores; R.A. Milvae; J. Yao; D.H. Poole and E.K. Inskeep (2009). Low peripheral progesterone and late embryonic/early fetal loss in suckled beef and lactating dairy cows. Theriogenology, 71:480-490.

Risco C.A.; G.A. Donovan and J. Hernández (1999). Clinical mastitis associated with abortion in dairy cows. J. Dairy Sci., 82: 16841689.

Sangsritavong, S.; D.K. Combs; R. Sartori; L.E. Amentano and M.C. Wiltbank, (2002). High feed intake increases liver blood flow and metabolism of progesterone and estradiol-17a in dairy cattle. J. Dairy Sci., 85, 2831-2842.

Santos, J.E.P.; H. M. Rutiglianoand M. F. SáFilho (2009). Risk factors for resumption of postpartum estrous cycles and embryonic survival in lactating dairy cows. Anim. Reprod. Sci., 110:207-221. 
Santos, J.E.P.; W.W. Thatcher; R.C. Chebel; R.L.A. Cerri and K.N. Galvão (2004a). The effect of embryonic death rates in cattle on the efficacy of estrus synchronization programs. Anim. Reprod. Sci., 82/83:513-535.

Santos, J.E.P.; R.L.A. Cerri; M.A. Ballou; G.E. Higginbotham and J.H. Kirk (2004b) Effect of timing of first clinical mastitis occurrence on lactational and reproductive performance of Holstein dairy cows. Anim. Reprod. Sci., 80: 31-45.

SAS. (2004). SAS/STAT User's Guide: Volumes 1-7. SAS Institute Inc., Cary, North Carolina.

Schrick, F.N.; M.E. Hockett; A.M. Saxton; M.J. Lewis; H.H. Dowlen and S.P. Oliver (2001). Influence of subclinical mastitis during early lactation on reproductive parameters. J. Dairy Sci., 84: 1407-1412.

Shahneh, A.Z. (2008). The Effect of GnRH injection on plasma progesterone concentrations, conception rate and ovulation rate in Iranian Holstein cows. J. Anim. Vet., Advances 7(9):1137-1141.

Silke, V.; M.G. Diskin; D.A. Kenny; M.P. Boland; P. Dillon; J.F. Mee and J.M. Sreenan (2002). Extent, pattern and factors associated with late embryonic loss in dairy cows. Anim. Reprod. Sci., 71: 1-12.

Snedecor, G.W. and W.G. Cochran (1989). Statistical Methods. $7^{\text {th }}$ Ed. lowa Univ. Press, Ames. lowa, USA.

Starbuck, M.J.; R.A. Dailey and E.K. Inskeep (2004). Factors affecting retention of early pregnancy in dairy cattle. Anim. Reprod. Sci., 84:27-39.

Stevenson, J.S.; S.M Tiffany and E.K. Inskeep (2008). Maintenance of pregnancy in dairy cattle after treatment with human chorionic gonadotropin or gonadotropin-releasing hormone. J. Dairy Sci., 91:3092-3101.

Thurmond, M.C.; J.P. Picanso and C.M. Jameson (1990b). Special report: Considerations for use of descriptive epidemiology to investigate fetal loss in dairy cows. J. Am. Vet. Med. Assoc., 197:1305-1312.

Thurmond, M.C.; J.P. Picanso and S.K. Hietala (1990a). Prospective serology and analysis in diagnosis of dairy cow abortion. J. Vet. Diagn. Invest. 2:274-282.

Vasconcelos, J.L.M.; R.W. Silcox; J.A. Lacerda; J.R. Pursley and M.C. Wiltbank (1997). Pregnancy rate, pregnancy loss and response to heat stress after $\mathrm{Al}$ at 2 different times from ovulation in dairy cows. Biology of Reprod., 56(1): 230.

Wiltbank, J.N.; W.W. Rowden; J.E. Ingalls; K.E. Gregory and R.M. Koch (1962). Effect of Energy Level on Reproductive Phenomena of Mature Hereford Cows. J. Anim. Sci., 21:219.

Zaborski, D.; W. Grzesiak.; I. Szatkowska; A. Dybus; M. Muszynska and M. Jedrzejczak (2009). Factors affecting dystocia in cattle. Reprod. Domest. Anim. 44:540-551. 
العوامل المرتبطة بفقد الحمل في الأبقار الفريزيان تحت الظروف المصرية

محمد عوض أبو الحمد، عبد الجواد خليفة قادوم ،ياسر مبروك الديهي وسليمان حسونة سليمان خلن فادوم

تهدف هذه الدراسة إلي تحديد العوامل التي تؤثر على فقد الحمل أو الإجهاض تحت

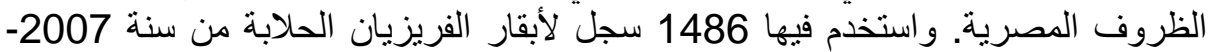

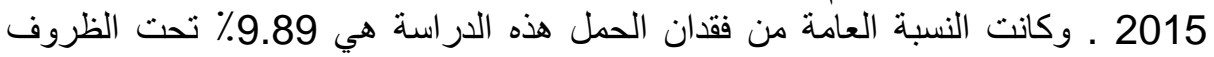

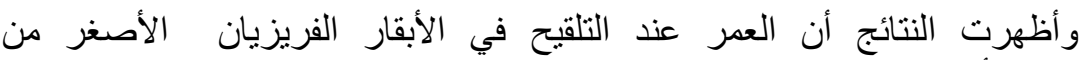

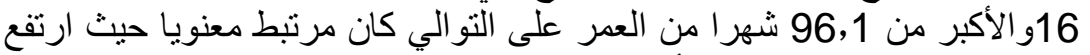

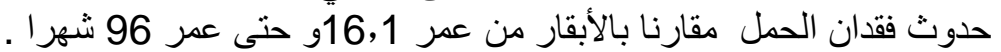

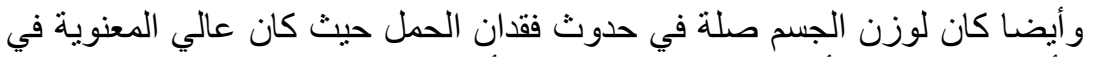

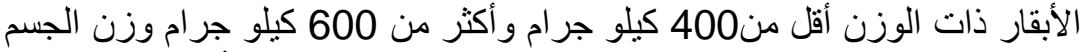

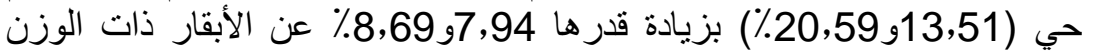
401 499 و 400 509 599 كيلو جر ام عند التلقيح على التو الي.

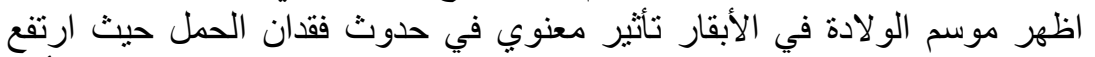

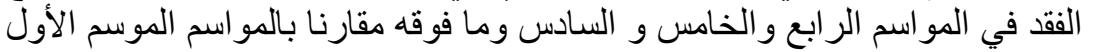
و والثاني و الثالث. وكذلك كان لفصل السنة تأثير معنوي حيث زاد فقد الحمل في فصل الصيف مقارنا

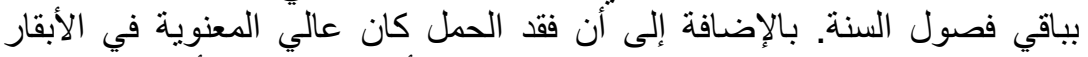

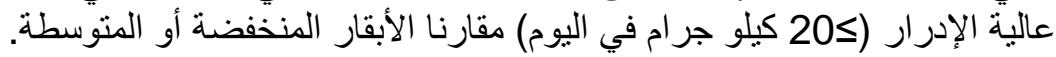

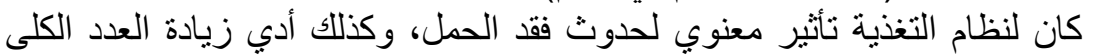

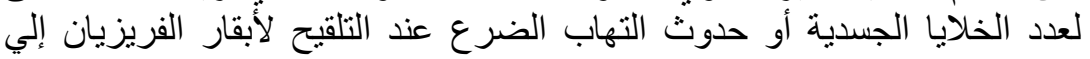

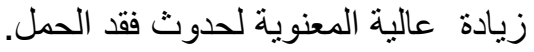

